\title{
HARDENBERGIA VIOLACEA (FABACEAE), IS IT NATIVE IN TASMANIA?
}

\author{
by A.M. Buchanan
}

(with one figure)

BUCHANAN, AM., 1994 (30:vi): Hardenbergia violacea (Fabaceae), is It native in Tasmania? Pap. Proc. R. Soc. Tasm. 128: 69-70. https://doi.org/10.26749/rstpp.128.69 ISSN 0080-4703. Tasmanian Herbarium, GPO Box 252C, Hobart, Tasmania, Australia 7001.

Hardenbergia violacea (Schneev.) Stearn is accepted as native in Tasmania.

Key Words: Hardenbergia violacea, Tasmania, Augustus Oldfield.

Hardenbergia violacea was first described (as Glycine violacea) by Schneevoogt (1793) from cultivated plants probably collected as seeds in the Sydney area in the first few years of settlement. This scrambling or trailing perennial grows from a woody rootstock and produces long wiry stems that climb on other plants or trail over rocky outcrops. It is well known in Victoria and New South Wales, where it occurs widely in dry open forests, but its occurrence in Tasmania is limited to the Pontos Hills near Richmond in the southeastern part of the state.

Some doubt has existed as to whether this plant is native in Tasmania. Curtis (1956) and Curtis \& Morris (1975) considered that it may have been introduced, and Willis (1972) questioned its status in Tasmania. Its singular occurrence, far from the mainland, in a farming district that had been occupied since the earliest years of European settlement, tended to support the assumption that it had escaped from a local garden.

The first definite reference to the genus Hardenbergia in Tasmania was that of Hooker (1859), based on specimens collected about 1857 by Augustus Oldfield on "rocky hills, near Frogmore, Richmond". Frogmore was a large grazing property near the present village of Penna; much of it has since been subdivided into smaller holdings.

Following Oldfield's collection of last century, no further collections are known until A. Moscal rediscovered the site and, some years later, in 1981, collected flowering material. The plants and their habitat appeared to be natural. Lynch (1993) described the population and its rocky sandstone habitat and accepted the species as indigenous.

Further evidence for its being native in Tasmania has recently come to light in the form of a short account in an early newspaper (Hobart Town Courier 1834). Assistant Surveyor William Malcolm, of the Survey Department, had been working in what was called the Sweetwater tier of hills near Richmond and had discovered a vine-like plant, not previously known to him. The plant was compared with Lempriere's (1954) description of Polygonum adpressum or Macquarie Harbour Grape (now Muehlenbeckia gunnii), of which it was thought to be a new species, but appeared "to be of a drier and more rigid quality". The leaves were "more fibrous and of rather a lighter green" and were "heartshaped", while those of Macquarie Harbour Grape were "winged" (fig. 1). Unfortunately, the plants were not in flower, depriving Malcolm of good diagnostic characters. However, the vegetative characters described, together with the locality, leave no doubt that this is the first record of Hardenbergia violacea in Tasmania. An early map by Surveyor Evans (1822) has the words "Sweet Water" printed in the position of the present Pontos Hills, making it clear that this is the area referred to.

It is possible that Oldfield, about 20 years later, knew of Malcolm's discovery, either through conversation or by reading the old newspaper account. In any event, his collections, forwarded to Joseph Hooker at Kew, England, established the identiry of the plant as a Hardenbergia. Hooker received the specimens just in time to include a description in the "Additions, Corrections, etc." that he appended to his Flora shortly before publication in late December 1859.

Hooker, however, placed the Frogmore material in Bentham's (1837) Hardenbergia ovata; perhaps Schneevoogt's earlier publication of Glycine violacea was unknown to him. Bentham (1864), in the first Flora for the whole of Australia, included the material in his (1837)

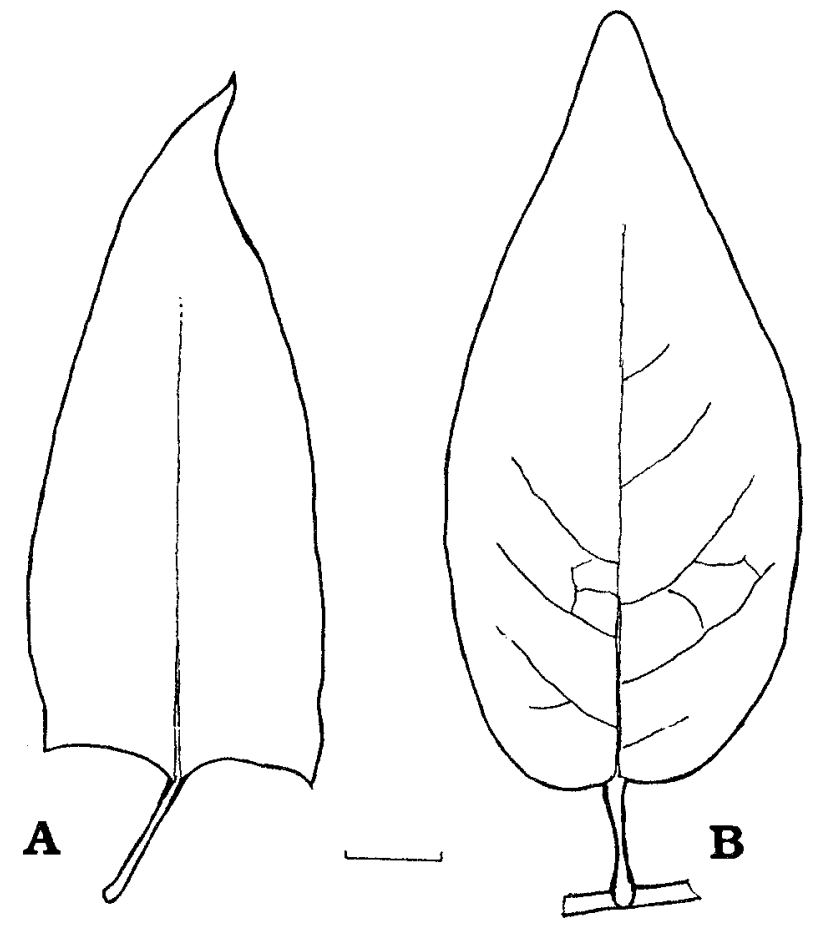

FIG. 1 - Typical leaves of (A) Muehlenbeckia gunnii and (B) Hardenbergia violacea showing the hastate ("winged") base of the former and the cordate ("heart-shaped") base of the latter. Scale bar $=10 \mathrm{~mm}$. 
H. monophylla. Rodway (1903), following Bentham, placed it in $\not R$. monophylla without commenting on its status. So far as can be judged, Rodway never saw the Frogmore plantis there are no specimens in his herbarium. It remained for Stearn (1940) to recognise Schneevoogt's G. violacea and its priority and to make the necessary new combination, $H$. violacea.

Thediscovery of this plant as early as 1834 provides good evidence for its being native in Tasmania, despite its highly disjunct distribution. Other plants with similarly disjunct dist ributions are Calocephalus citreus (Asteraceae), Isoetopsis graminifolia (Asteraceae), Thesium australe (Santalaceae), perhaps now extinct in Tasmania, Pultenaea pedunculata (Fabaceae) and Eryngium ovinum (Apiaceae). All are species of open, dry, warm habitats and were probably widespread in eastern Tasmania during the postglacial climatic optimum, but were later confined to the refugia in which we now find them.

\section{REFERENCES}

Anon., 1834: Hobart Town Courier, 14 March: 2, col.5. BENTHAM, G., 1837: In Endlicher, S.L. et al:: Enumeratio Plantarum quas in Novae Hollandiae ora austrooccidentali ad Fluvium Cygnorum et in Sinu Regis Georgii collegit Carolus Liber Baro de Hügel. Fr. Beck, Vienna: 41.

BENTHAM, G., 1864: FLORA AUSTRALIENSIS 2: 246.
CURTIS, W.M., 1956: THE STUDENT'S FLORA OF TASMANIA 1. First edn, Government Printer, Hobart: 166.

CurTIS, W.M. \& MORRIS, D.I., 1975: THE STUDENT'S FLORA OF TASMANIA 1. Second edn, Government Printer, Hobart: 169

EVANS, G.W., 1822: A GEOGRAPHICAL, HISTORICAL AND TOPOGRAPHICAL DESCRIPTION OF VAN DIEMEN'S LAND. J. Souter, London. (The fold-out map is dated 1821.)

HOOKER, J.D., 1859: FLORA TASMANIAE. Lovell Reeve, London.

Lfimpriere, T.J., 1954: The penal settlements of early Van Diemen's Land. Roy. Soc. Tasm. (Launceston Branch): 44. (Printed from Lempriere's original manuscript.)

LYNCH, A.J.J., 1993: Conservation biology and management of 16 rare or threatened Fabaceae species in Tasmania. Austr. Nat. Pks \& Wildl. Serv. Endangered Species Program. Proj. 4. Dep. of Environment and Land Management, Hobart.

RODWAY, L., 1903: THE TASMANIAN FLORA. Government Printer, Hobart.

Schnemvoogt, G.V., 1793: ICONES PLANTARUM RARIORUM 1. Haarlem: t.29.

StEARN, W.T., 1940: Schneevoogt and Schwegman's Icones Plantarum Rariorum. J. Bot. 78: 70.

WIL.IIS, J.H., 1972: A HANDBOOK TO PLANTS IN VICTORIA 2. Melbourne University Press: 312.

(accepted 20 April 1994) 